\title{
Aryan Mundus and Sexual Inversion: Eliot's Edition of Nightwood
}

MARGARET VANDENBURG

$\mathrm{D}$ ESPITE its notorious seXual politics, Djuna Barnes's Nightwood gained considerable literary respectability when T. S. Eliot endorsed the first American edition with his Introduction. The presiding dean of Modernist letters at Faber and Faber in London, Eliot could distinguish even obscure writers with a single stroke of his editorial pen. Though his decision to publish Djuna Barnes's wildly subversive Nightwood suggests that an antic disposition lurked beneath his studied propriety, he expurgated several of the manuscript's most transgressive episodes, thus diminishing the redemptive role of sexual inversion in the novel. Eliot admits in his Introduction that "it took me, with this book, some time to come to an appreciation of its meaning as a whole" (xi), but his editorial deletions indicate he overlooked the symbolic significance of inversion as the antithesis of Aryan essentialism in the manuscript. With uncanny prescience, Nightwood forecasts the nightmare of Nazi genocide and gendercide, ${ }^{1}$ creating a Parisian underground of expatriate inverts in exile from the deadly cultural "hygiene" of fascism. Analysis of the deleted manuscript passages restores the full force of Barnes's antifascist polemic in which inversion ultimately wins the day.

In the canon of Barnes scholarship, the "text bashing" of the manuscript of her play The Antiphon has received considerable attention, but analysis of Eliot's editorial influence on Nightwood is still a critical frontier. The controversy surrounding The Antiphon is instructive insofar as deletions seriously compromised the thematic coherence of both published works. According to Lynda Curry, The Antiphon never recovered from Eliot's overly aggressive editorial intervention: "since the first moment it appeared in print, it has been subjected to vehement critical attack" (287), resulting in part from the absence of key passages cut for the sake of brevity and readability. Barnes's most famous and baleful cry for preserving the dramatic unities of The Antiphon exemplifies how the 
editorial process had evolved into a tortuous experience: "And Tom, do take mercy on the author who has been twenty months in a fairly gruesome state of tension" (cited in Curry, 286). Early critics such as Andrew Field blame Barnes herself for the play's obscurity, minimizing the editorial impact of "Eliot and Muir, who were trying to play Pound to her Wasteland" (225). Although The Antiphon's publication history is considered more problematic than Nightwood's, manuscript studies reveal that Tom did not "take mercy" on the thematic integrity of either work.

The correspondence between Barnes and Eliot concerning Nightwood's editorial process is less plentiful and adversarial than that surrounding The Antiphon, but a number of motives and criteria emerge in their letters. From Barnes's perspective, she was clearly flattered by Eliot's attention and, absolutely committed to getting the novel into print, she gave him editorial free rein. In a letter to Barnes dated August 10, 1956, Eliot's own comparison of editing Nightwood and The Antiphon illustrates his willingness to "sacrifice" thematic intricacies when they interfered with concise readability:

It seems to me what is needed is much more drastic cutting, twelve to fifteen pages. ... I know it is painful to sacrifice what one feels to be good lines, but you had to cut a good deal, you will remember, out of "Nightwood," stuff which was quite good enough to stay in, except that there was too much of it. (Barnes Collection)

Given the fact that Barnes herself had already edited "Bow Down" (the title of the original manuscript of Nightwood) from 190,000 words down to 65,000 before submitting the text to Eliot at Faber and Faber, she had clearly already acknowledged the virtues of brevity. In a letter describing more specific motives, Eliot also insisted that his deletions were designed to assure that Matthew O'Connor would not monopolize the work or compromise the focus on the ill-fated, even abusive relationship between Robin and Nora Flood. ${ }^{2}$ As a result, inversion is more pathological and tragic than transgressive and redemptive in Eliot's published edition of the novel.

With these professed criteria, Eliot deleted or altered the most risque references to Matthew O'Connor's renegade sexuality. As if to spare the cultured sensibilities of his audience, he cut rollicksome lines whose semiotic function went well beyond mere campy humor: "you can lay a hundred bricks and not be called a brick layer, but lay one boy and you are a bugger" (Ms., 202). In Nightwood, the sexual is political. Hence, far from merely bawdy, words like "bugger" are linguistic monikers of transgressive liberation, and their absence undermines the polemical impact of the novel. In this case in particular, Eliot's deletion of Matthew O'Connor's bricklayer quip erases a foreboding example of Nazi reductionist essentialism, the eth(n)ical premise of racial and gender cleansing. 
Eliot's most significant editorial deletions consist of four lengthy scenes, one in which Matthew performs serial circumcisions on a battalion of doomed soldiers, and three legends of transgressive "queens" Marie Antoinette, the tortured homosexual Ludwig of Bavaria, and Matthew himself - who transcend their stigmatized roles as Nazi scapegoats to become the royal family of a countercultural kingdom of the Night. Underlying Eliot's ostensible editorial criteria, his correspondence and the actual deletions themselves reveal more telling motives than mere structural pruning. Without committing the intentional fallacy he and the New Critics so abhorred, it is nevertheless evident that Eliot's editorial criteria were less determined by "too much of a good thing" and more by conventional propriety and, if not prudery, a certain Prufrockian discomfort with Barnes's unabashed exploration of the political ramifications of sexual inversion.

Early poems such as "Bullshit," "Ballad for Big Louise," and his lusty limericks about "King Bolo and his hairy Big Black Kween" suggest that Eliot himself once had a flair for the bawdy. Yet very little of this ribaldry survived Eliot's expatriation, his editorial authority at Faber and Faber, and his immediate ascension to Modernist canonicity upon the publication of "Prufrock" and The Waste Land. He and his own high-priest editor Ezra Pound often edited out this carnivalesque side of his own poetry, the unpublished fragments that revealed more than they concealed and were therefore not ultimately included in Eliot's Collected Works.

Though Eliot proved capable of conflating high and popular culture in his "Shakespeherian Rag," Barnes herself pointed out that his double vision sometimes failed him: "I don't know what to make of it ... his cultivation of Groucho Marx, (his picture on Tom's office wall, and mine, if you noticed, just above it" (letter to Peter Hoare dated January 1965). ${ }^{3}$ Though she may have underestimated Eliot's "antic disposition," there is no doubt that his editorial deletions undermine the full range of carnivalesque transgression in Nightwood. As an editor, he "asserted himself with a simple pin" of Prufrockian propriety, averting the reader's gaze from the most "indecent" and therefore most ultimately redemptive passages in the manuscript which, denying the very prurience of his editorial assumptions, states that the "indecent' is the eternal" (Ms., 197). As was the case with The Antiphon, a "slow development toward the tragic and away from the comic" (Curry, 297) resulted from his editorial influence. Though Eliot may have found "delight in disorder," he mixed business with pleasure only to a point; as an editor, his Poundian rather than Marxian sensibilities prevailed.

In his 1937 Brooklyn Daily Eagle review of the novel and its Introduction, C. L. Watson notes that, "Mr. Eliot derived a certain moral uplift from not disapproving," with the result that he manages to "intrude his religious beliefs into the most ordinary kind of literary criticism, and on that account I feel his introduction is in one respect unreliable" (16C). Virtually all of Eliot's editorial deletions reflect this "moral uplift." For 
example, his Anglican sensibilities must have been offended when Doctor O'Connor utters "Christ's sweet foot" (Ms., 87) as he "wave[s] his hand in a gesture of abandon" in the Champs-Elysées, implicitly associating Christ with a sexually charged gesture. Famous for her verbal caricatures, Barnes herself encapsulates Eliot's High Church propriety: "Poor Eliot, he kept his organ in the Church" (cited in McCullough's "Reminiscences," 367). ${ }^{4}$ The barb in this quip is characteristically playful and sharp and has particular relevance to Eliot's reading of Nightwood. Though the raucous transgression of the novel obviously appealed to Eliot to the extent that he championed its publication, remembering "his organ in the Church" sometimes reined in his appreciation of myriad references to the characters' sexual organs in the manuscript. Not surprisingly, in a novel that advocates the redemptive potential of sexual inversion, genitalia enjoy an exalted stature as the site of transgressive "nature." Matthew O'Connor's anecdotes, especially those deleted by Eliot, are predominantly concerned with the dangerous repercussions of Nazi "culture's" denial of nature, both from an ethical and a genital point of view.

Barnes's attitude toward Eliot's capacity as editor was ambivalent, as was her assessment of criticism in general, which she characterized as "often nothing more than the eye garrulously denouncing the shape of the peephole that gives access to hidden treasure" (cited in Broe, 8 ). While publicly she praised Eliot's Introduction and acknowledged her debt to his patronage, she was often privately critical, even of the Introduction ${ }^{5}$ which, she confided to friends, "was acceptable only because it had been written by Eliot" whose patronage was a double-edged sword (Field, 219). Though for the most part they maintained a polite if not cordial correspondence, as her disappointment with Eliot's professional expertise escalated, so did the virulence of her barbed disillusionment. By the time her play The Antiphon was put through its grueling editorial paces in 1957, Barnes had lost patience with her editor. ${ }^{6}$ Comparing Janet Flanner and Eliot as readers of The Antiphon, Barnes lamented: "I never expected to find that you were as stupid as Tom Eliot" (Flanner, xviii). Yet the seeds of her discontent had already been sown as early as Nightwood, whose "peephole" is inversion itself.

Barnes's choice of inversion as the symbolic antithesis of Nazism stems from the epistemological status of sexuality in Modernism. In the psychoanalytic context of literary texts, gender is the very locus of meaning, initially constructed in response to the so-called Oedipal Law of the Father - Freud's reality principle and Lacan's Symbolic Order - whose first commandment outlaws pre-Oedipal bisexuality. ${ }^{7}$ As Modernism's most persistent metaphor, gender also signifies the psychological internalization of external phenomena so that World War and the rise of fascism are often reflected through the lens of sexual politics. Hence, Gertrude Stein blames World War II on the problem of "too much fathering going on ... there is father Mussolini and father Hitler" (Everybody's Autobiography, 113), a sentiment echoed by Virginia Woolf in both A Room of One's Own 
and Three Guineas. ${ }^{8}$ Similarly, as Djuna Barnes prophesies with uncanny prescience, in the years following the publication of Nightwood, Hitler asserted his patriarchal authority: "As for God and the Father - in Austria they were the Emperor" (33). Since androgyny is the equivalent of the pathological persistence of pre-Oedipal bisexuality within the symbolic realm of Modernism, Barnes casts the androgynous Robin Vote and Dr. Matthew O'Connor as the protagonists of the Night and as the antagonists of tyrannical authorities ranging from psychoanalysis to fascism. Their inversion thwarts the Law of the Father, as did the bisexuality and homosexuality of Modernist gender theorists including Barnes, Woolf, and Stein.

Barnes's valorization of inversion clashes with the psychoanalytic denigration of inversion as deviance in a prefiguration of World War II. The latter sexological account of inversion as pathology was seized upon by Nazi rhetoricians as a justification for gendercide, just as Wagner and Nietzsche were co-opted to add pomp and heroic panache to genocide. Where Radclyffe Hall's The Well of Loneliness reflects the standard sexological approach to inversion as perversion "associated with a kind of essentialism ... or frequently involved in a morbidification of what had earlier seemed innocent because unlabeled" (Gilbert and Gubar, 216), ${ }^{9}$ Barnes's inverts are clearly not spawned from Havelock Ellis, Edward Carpenter, or Richard von Krafft-Ebing's essentialist gene gender pool. ${ }^{10}$ Robin herself is a mother and bisexual; in fact, one of the reasons Barnes refused to minimize Felix's role in the novel was that Barnes wanted to establish Robin's homosexuality or inversion as chosen rather than essential.11

Djuna Barnes's most telling private response to Eliot as the editor of Nightwood actually appears in the margins of the manuscript's final page: "Sample of T.S.E.'s 'lack of imagination' (as he said)" (Ms., 215). This is Barnes's last word, literally, on Eliot's editorial performance. Her frustration with his "lack of imagination" is a direct response to his having written "unclear" next to the concluding paragraph of the original manuscript of "Bow Down." Depicting the final ritual of inversion enacted by Robin and her dog/God, this scene signifies her flight from the essentializing culture that has tried to tame her since her first appearance as "a woman who is beast turning human" in "La Somnambule" (37). Robin escapes through regression not only to pre-Oedipal bisexuality but also to bestiality, two taboos that are glorified by the thematic trajectory of inversion in the manuscript, especially in the passages deleted by Eliot's editorial prerogative. Thus, the exact nature of Eliot's "lack of imagination" is allied with his failure to recognize regression as progression in the inverted world of the Night.

Given the Darwinian premise of species evolution, the Aryan myth of racial superiority, and Freud's own paradigm of the progression of each individual from "innate bisexuality" to gender exclusive maturity, Nightwood's rejection of the efficacy of progress is historically profound. In Jane Marcus's seminal analysis of Nightwood "as a prophesy of the Holocaust" (249), ${ }^{12}$ she situates the novel's attack on official Nazi ethics in the larger 
context of the ambivalent marriage of the carnivalesque (mundus inversus) and the canonical (mundus) throughout Barnes's oeuvre. ${ }^{13}$ In this context, Eliot's "lack of imagination" also stems from his misapprehension of Nightwood's redemptive "two world condition" - mundus and mundus inversus - a double vision that cultural historians including Bakhtin and Jung lament has been largely lost in modernity. ${ }^{14}$

Marked from the beginning of Nightwood as a mythic personification of the "converging halves of a broken fate" (38), Robin recovers this lost "two world condition." As prophet of the Night, Robin's harbinger, Matthew O'Connor, provides a succinct paradigm of mundus inversus redemption when he describes himself as an "angel on all fours" and counsels his disciples - the homosexuals Nora Flood and Jenny Petherbridge and the Jewish Felix Volkbein - to aspire to his ethic of inversion: "May you be damned upward!" (95). Analyzing the political ramifications of carnivalesque crownings in "Laughing at Leviticus," Jane Marcus clarifies the distinction between fascist mundus and sexual inversion:

Inversion reveals the essence of the particular historical moment that we construct as the "rise of fascism" in the "upright" defining their differences from the abject by race, gender, or sexual practice.... In carnival, enthronement of the fool implies dethronement of hierarchy. (247)

The logic behind the efficacy of mundus inversus is patently simple: the status quo is damned; therefore, to transgress is to redeem. Inversion is an ideal. The most profound effect of Eliot's manuscript deletions is that, by erasing the enthronement of sexual inverts, including Ludwig of Bavaria, Marie Antoinette, and Matthew's carnivalesque double MacClusky, the positive potential of abjection is undermined.

Without being privy to this carnivalesque transformation of degradation into transcendence, the redemptive role of regression in the final chapter of the novel proves particularly difficult to interpret with sufficient thematic depth and coherence. En route to this comic denouement, the novel evolves through three main thematic stages - mundus, mundus inversus, and carnivalesque crowning. Called the "female Rabelais" (226) by Marcus, Djuna Barnes's description of James Joyce's Ulysses as a "great Rabelaisian flower" exemplifies her vision of Modernism through this lens of carnivalesque mundus inversus ("James Joyce," 295). In particular, Mikhail Bakhtin's celebration of carnivalesque redemption in $R a$ belais and His World provides a comprehensive theoretical backdrop for the novel's complex three-tiered polemical and aesthetic structure:

Rabelais' basic goal was to destroy the official picture of events. He strove to take a new look at them, to interpret the tragedy or comedy they represented from the point of view of the laughing chorus of the marketplace. (439) 
In the historical context of Nightwood, the "official picture" is the Nazi essentialist denigration of Jews and homosexuals as racial scapegoats and sexual inverts, subject to fascist "cleansing." Against this backdrop of Nazi hierarchies, the protagonists of the Night - the Jewish Felix Volkbein, the African-American Nikka, the lesbians Nora and Jenny, and the androgynes Robin and Matthew - form a transgressive band of outlaws whose very "lack of connection with the canons and norms of all completed, authoritarian, and dogmatic" (127) forces constitutes their fortuitous mundus inversus of fascism in the novel. ${ }^{15}$

Matthew and Robin's embodiment of mundus inversus suggests that sexual inversion is especially redemptive because it flouts the law of Austrian fathers. Whereas Robin is a mother who utterly rejects domesticity in favor of prowling Nightwood, Matthew functions as a carnivalesque father figure, the high priest of the Night: "Or is confessing bottom up (though keeping the thread in the tatting), to a priest who has the face of a butcher, and the finger of our own right hand placed where it best pleases" (Ms., 103-4). Though this passage might at first seem a gratuitous juxtaposition of masturbation and the sacrament of confession, it also underscores Matthew's role as father confessor to Nora Flood and other acolytes of the Night. If Woolf and Stein were right in assessing fascism as the result of "too much fathering going on," then Matthew O'Connor's new brand of androgynous fatherhood, dominated by womb envy, provides a felicitous alternative. Dr. Matthew-Mighty-grain-of-saltDante-O'Connor's transgressive tirades stem the tide of the Nazi reign of terror against inversion. An impotent male homosexual with "a terrific widow's peak... whose interest in gynaecology had driven him half around the world" (14), Matthew is obviously a personification not only of inversion but also of the transcendent androgyny that Robin Vote, the heroine of the Night, epitomizes.

Androgyny is at the center of mundus inversus in Nightwood because the androgyne is by definition not bounded by the "merely individual meaning of the life of one single, limited body" that characterizes the canonicity of official culture:

The body of the new canon is merely one body; no signs of duality have been left. It is self-sufficient and speaks in its name alone. ... Therefore, all the events taking place within it acquire one single meaning: death is only death, it never coincides with birth; old age is torn away from youth; blows merely hurt, without assisting an act of birth. (Bakhtin, 321-22)

Where mundus "speaks in its name alone" - the name of "too much fathering going on ... father Mussolini and father Hitler" - the androgyne as gender mundus inversus constitutes the archetype of duality without the qualifications of hierarchies or canonicity. Predictably, as Bakhtin points out, "[t]he androgyne theme was popular in Rabelais' time" (323). Just as 
Rabelais' carnivalesque double vision "contributed to the destruction of the medieval hierarchic picture of the world and to the creation of a new concept" (362), so too Nightwood's androgynous vision replaces Nazi mundus - what might be called the "Daymetal" of militaristic official fascism - with the mundus inversus of Nightwood - the carnivalesque transgression of circus performers, Jews, homosexuals, and the double vision of the androgynes Matthew and Robin, the prophetic saviors of the Night.

In terms of the novel's structure, Barnes presents the three-tiered movement toward redemptive inversion in a roughly chronological format, beginning with mundus, represented by Felix's parents, Hedvig and Guido Volkbein, exemplars of the "happy German people" who support the regime of Daymetal. Then mundus inversus is portrayed through the portraits of Nikka and Mademoiselle Basquette, two circus performers whose outrageous bodies defy the "hierarchic picture" of fascism. Finally, as carnivalesque shaman, ${ }^{16}$ Matthew O'Connor transubstantiates temporal shame into spiritual victory, with "spiritual" being defined as that which advances both strata: soul and body, nature and culture - a mundus inversus heavenly system where angels defecate as well as fly.

Given Eliot's High Church sensibilities, his derogatory reading of inversion and shame as degradation is not surprising, but to Matthew these supposed maladies are gateways to grace: "Wait! I am not using that word ['maladjusted'] in the derogatory sense at all; in fact my great virtue is that I never use the derogatory in the usual sense" (116-17). Only the erasure of degradation is "ignoble" or "derogatory." Nightwood reclaims the sanctity of shame. Eliot's editorial deletions "use the derogatory in the usual sense" and reverse this salutary reclamation. Consistent with Eliot's inveterate canonicity, the humiliation of ghettoized "inverts" is perfectly acceptable, even supportive of hierarchic visions of high culture. But when abjection and inversion are celebrated by the carnivalesque crownings of major historical figures like Ludwig of Bavaria and Marie Antoinette, or characters elevated by official military positions like MacClusky, their mundus inversus enthronement is consistently edited out.

Eliot's integrally linked deletions, totaling fifteen pages in all, form a thematic objective correlative that clarifies the novel's most political dimension: Nightwood's last-ditch dramatization of the fact that so-called inverted, Nightwood natures are not safe in the dark; they need official sanction, even as sanctioned transgressions, in order to survive the Daymetal of the increasingly militaristic fascism of official culture initially personified by "Hedvig Volkbein - a Viennese woman of great strength and military beauty" in the first chapter of the novel, "Bow Down" (1). Amidst Matthew's countercultural litany of legendary transgressors of the Night, he pauses to warn twittering interlocutors that their smug false security will not protect them from Daymetal's censorious "hand of power": 
Someone laughed. The doctor turned slowly. "So safe as all that?" he asked sarcastically; "so damned safe? Well, wait until you get in gaol and find yourself slapping the bottoms of your feet in misery." (158-59)

In 1936, no one was safe from political, cultural, or editorial censorship.

Eliot's first major editorial deletions from the manuscript consist of Matthew's sympathetic portraits of Ludwig of Bavaria and Marie Antoinette. Traditionally portrayed as licentious scapegoats of official culture, Matthew demonstrates that, unofficially, they are actually "nature's noblemen" (15). ${ }^{17}$ These two revisionist biographies culminate in an account of Matthew's imprisonment in the Parisian cell once inhabited by Antoinette, incarcerated for his supposedly "indecent" attention to his "nature." In fact, all three "blasphemed queens" - Matthew, Marie, and Ludwig-suffer humiliation at the hands of a particularly "hygienic" culture for the supposed perversion of their natures. They are all in danger of being "civilized" to death or, as Matthew puts it, "washed ... too clean for identification" (90). This problem of scapegoating so-called inverts recalls the dangers of reductionist labeling most vividly demonstrated in Matthew's spurious distinction between bricklayers and buggers. Constituting a full third of the original second chapter - nine almost continuous pages - Eliot's elisions erase the historical context of the dangers of cultural cleansing that make the impending entrance of a natural, primitive hero such as Robin such an imperative in Nightwood.

A connoisseur of music, theater, art, and taboo forms of love and sexuality, Ludwig the Mad reminds Matthew of his own imperiled nature. Comparing himself with his royal precursor - "nature's nobleman" O'Connor concludes that neither he nor Ludwig are actually "infirm," despite the censure of intolerant historical climates:

"So what of Ludwig? Called infirm because he'd had everything but a woman and a lace collar - and I wouldn't be too sure about the lace collar.... So I often think, what kind of nature was it this man had, sitting there in his Winter Garden where he - all by himself - listened to music, riding about on his lake dressed up like Logengrin [sic] in a boat like a swan. What's so crazy in that? If wanting a theatre all to yourself is madness I'm madder than most; and if screaming would empty the world out I'd scream until I broke." (Ms., 28-29)

Matthew attributes the king's eccentric behavior to connoisseurship rather than to the so-called pathology of sexual perversion. Far from depraved, Ludwig's romantic affiliation with Wagner actually engenders Romantic genius: "So I stood there thinking what must have been in his heart when he sent for Wagner - can't you see Wagner creeping up the stairs with his blood pounding the script of an opera under his arm?" (Ms., 
29). But like Matthew, Ludwig is doubly censored, first historically and then textually by Eliot's editorial intervention.

Describing a religious shrine Ludwig built to try to counteract the temptation of "blood pounding," Matthew invests the word "nature" with a double entendre:

“... one day [the Mad King] forgot himself and put a hand on his nature, whereupon his rosary fell and lay there weeping. He had it inlaid, and when he felt that he was about to lay hands on himself, he put his best foot forward and over that sign and prayed like a good Wittlsbach that his hand might be withheld." (Ms., 29-30)

As in all of the deleted legends about sexual inversion, "nature" refers both to what Gertrude Stein calls "bottom natures"18 - each character's defining characteristics - and to their lower bodily natural parts, namely, their genitalia. Due to canonical commandments symbolized by the rosary, Matthew must "forget himself" in order to be himself; he must reject prescriptive culture in order to "put a hand on his nature." In the life of the historical Ludwig, this paradox contributed to the demise of the king whose diary "reveals an acute sense of carnal guilt" that became increasingly instrumental in "the writer's mental deterioration," culminating in suicide (McIntosh, 157). ${ }^{19}$ Similarly, in Nightwood, Ludwig commits suicide in an effort to secure liberty to love according to his true nature:

"I asked Munchen's good women why they thought him mad. They said, 'a king has all privileges, but mustn't use them.' 'Sounds like love,' I said, 'all the love in the world and none of it used.' He, possibly, came to the same conclusion. . . . Well, he ended it all," he continued, "by drawing the waters of Starnberg over him, after that he could do as he pleased.... And it's strange and awful how many people there are who can do what they want only off a roof, or through a rope, or under water, or after the shot is silent." (Ms., 30)

"Good women," the purveyors of culture, are repeatedly depicted as the enemies of nature in the novel. Internalizing their prohibition against homosexual love, Ludwig finally destroys himself. But in the mundus inversus realm of the Night, his silence is eloquent, foreshadowing Robin Vote's "powerful and willful silence" (Ms., 133). Far from acquiescent, his suicide constitutes a refusal to continue to deny his nature.

Ludwig's saga also serves as a preamble to the Doctor's own incarceration in Marie Antoinette's cell as punishment for "crimes against nature" identical to those of Ludwig. Also deleted from the published novel, Matthew's account of his imprisonment presents a similarly ambiguous nexus of the transgressive accoutrements of inversion - masturbation, homo- 
sexuality, androgyny, and love - and their relationship to the Doctor's nature. His reminiscences about Ludwig's castle put him in mind of his own "palatial mansion" and androgynous "rows of old dresses in silks that could stand up by themselves - they could have gone to war just as they were" (Ms., 32). Pursuing these free associations, the Doctor then penetrates to the heart of his portrayal of both Ludwig and Marie Antoinette as historical doubles of himself:

“. . . you could tell by the way the bum bird-cages of bustles stood that they [were] not afraid of love no matter what was going on. And speaking of love," he said, "I love nature as well as anyone, things all growing quietly, getting used up and dying and saying nothing, that's why I eat salad - which brings me to the night I popped Tiny out to relieve him of his drinking, when something with dark hands closed over him as if to strangle the life's breath out of him and suddenly the other, less pleasing hand, the hand of the law, was on my shoulder and I was hurled into jail, into Marie Antoinette's very cell ... two blasphemed queens." (Ms., 32-33)

Just as Ludwig refers to sexual stimulation as putting a "hand on his nature," so here the Doctor embarks on an encoded discussion of the life of Tiny, his penis and the central agent of his lower bodily nature. The mock negativity of "something with dark hands... strang[ling] the life's breath out of him" disguises an encoded Renaissance death, or orgasm. Where Ludwig's suicide is caused in large part by his frustration with "all the love in the world and none of it used," Matthew has improved on this enforced celibacy to the extent that he enjoys "nature," phallic sexual intercourse, "as much as anyone, things [penises] all growing quietly, getting used up and dying [orgasms] and saying nothing." But all of this love of nature is done "quietly," and he is safe only in "saying nothing." The minute the Doctor's phallic manhandling becomes public, he is hurled by the "less pleasing hand, the hand of the law" into the cell of Marie Antoinette, a French Oscar Wilde to the extent that she was incarcerated in large part for rumors of sexual decadence.

The Doctor's incarceration abounds with additional parallels with both Ludwig and Marie, most notably the shame and misery of lost love, a "heart breaking" and "bleeding," and a suicide watch on the part of his accusers and jailers. In his despair, Matthew appeals to Notre Dame de la Bonne Garde, praying, "Why did you have me if you didn't want me ... and weren't going to help me in our hour of trouble!" (35). Finally, Matthew's prayers are answered by what amounts to the first carnivalesque crowning in the novel, an official acknowledgment of his Nightwood nature:

"And at that Notre Dame de la Bonne Garde seemed to sort of give me the high wink, and the judge let me off after all! So, as I 
went by him I whispered: 'I thank you, and I love you very much, de tout mon coeur!' He answered, soft and low, stabbing the blotter with a pencil: C'est le coeur d'une femme!' 'Oui!' I said gentle, so perhaps I've got me a friend." (Ms., 35)

With a gesture replete with the homoerotic innuendo that consistently accompanies even the most official occasions, O'Connor is liberated, thus escaping the fates of his historical predecessors Ludwig and Marie death due to "natural" transgressions. Judging from the judge's suggestive reference to Matthew's "coeur d'une femme," O'Connor is set free because of rather than in spite of his androgynous nature, thus reversing the status of inversion in classic carnivalesque fashion. But Eliot deleted this paradigm of redemptive inversion.

Matthew O'Connor's relief upon liberation is tempered by his somber disputation on the tragedy of silenced natures, a dirge with twofold significance in light of Barnes's silencing editor. The Doctor's characteristic satiric tone is muted as he dons the posture of the philosopher, penetrating the menace hidden beyond Nightwood:

"I think it's a terrible world - this extremity, this badly executed leap in the dark called life. So I was thinking ... my hands to my lip, saying, 'Tragedy,' softly, saying, 'Horror,' softly, saying 'Violence!' Silence, may it stand beside my mouth - note the Greek in that posture, the gesture histrionic! At that moment I was, for misery, as slain of detail as a marble from Carthage."

"If they must punish you for forgetting yourself - as if that were not awful punishment enough," he said reflectively, "Why don't they come to your house in the dark, when no one is looking, and let your drawers down and beat you up? It would be better for the pride of the race." (Ms., 35-36)

The "race" living in "this extremity, this leap in the dark called life" consists of androgynous inverts who, though safe in the "dark" of Nightwood, are punished when they "forget themselves" and expose their true natures. The double entendre on "forgetting yourself" is a Catch-22 plight: to forget oneself in order to "grasp one's nature" is to transgress, but to forget oneself by denying one's nature is "awful punishment enough." In every single major elided passage, "beat up" is used to describe the punishment of exposed androgynous natures; when the silence of anonymity is penetrated, violence threatens. Yet silence itself - "the gesture histrionic!" - is potentially even more devastating: not merely humiliating but fatal.

The only exit from this vicious circle of silenced inversion is the official approbation enjoyed fleetingly by $\mathrm{O}^{\prime}$ Connor in the denouement of this first and longest editorial elision - the full eight pages deleted from " $\mathrm{La}$ 
Somnambule" that set the precedent of the transformation of humiliation into carnivalesque crowning in the manuscript. The paradigm of this redemptive transformation is even more fully fleshed out in Eliot's second major deleted passage - the Decorated Nancy episode - in which an androgynous soldier is officially honored. This second carnivalesque crowning constitutes the elided objective correlative of the novel's mundus inversus celebration of transgressive and redemptive natures. Although the Decorated Nancy episode is a mere one and a half pages long and might be dismissed as burlesque comic relief, it provides a thematic emblem when read as the culmination of the major cuts Eliot performed on the manuscript. Even more blatantly than with the Ludwig/Marie omissions, the thematic result of this deletion from the chapter titled "Where the Tree Falls" is the obfuscation of Nightwood's valorization of sexual inversion.

The legitimization of the soldier MacClusky, ${ }^{20}$ a "girlish boy" decorated for valor, provides the official approbation that vindicates the entire "race" of inverts, Jews, and other Aryan outcasts. Known for his impeccable makeup and "swishing into the air," MacClusky effects a mock heroic escape from a "douse of Germans" (Ms., 134-36). Unable to distinguish "one end of a gun from another," he "went all of a fluff" and began whirling and swinging the heft of his gun, presumably in a dancerly pirouette fashion, dispersing confused German soldiers more accustomed to gunfire than to the "swishing into the air" of a "poor bewildered moll." MacClusky escapes the bloody "field of mincemeat" thanks to his androgynous deviation from masculine combat decorum; he survives through his gender mobility in a literal sense.

When MacClusky's misguided military superiors mistake his terrified antics for bravery, "the general comes up prancing and pinning and kissing the elect" with combat medals of honor. Matthew O'Connor is particularly entertained by this spectacle "because MacClusky was just the kind that should have a consignment of medals left at his door for breakfast every day." Punning on "medals" as symecdochic signifiers of servicemen, Matthew envisions MacClusky as a "moll" servicing "medals" with sexual favors, erotic valor on a "field of mincemeat." Despite the burlesque presentation of the medal, the general "prancing and pinning and kissing the elect" as if an unwitting participant in the moll's sexual court, MacClusky is genuinely moved by this unwonted acknowledgment of legitimacy.

In a historical context, being one of the "elect" means survival in the face of fatal fascist predestination. A fellow Irish invert, O'Connor places himself in MacClusky's uniform, savoring the fleeting validation:

" 'Here's where I come into something that will take away the ignominy of my past, and the marrow of my nature will be refilled and made glorious' for he had been so far away and beaten up in his heart for the opinion the world had of him and everybody has it, no matter what they say - ... when 
down on his breast flew the croix de guerre ... and with a great joy swelling and rolling him along." (Ms., 136)

Like Matthew, Ludwig of Bavaria, and Marie Antoinette, Mac is "beaten up" for his transgressive sexual nature; unlike Ludwig and Marie, whose deleted biographies in Nightwood end in suicide and death, Mac rejoices and triumphs in the wake of official approbation that "tossed him up into a shape of approval." This carnivalesque crowning elevates MacClusky's inversion to the exalted level of androgynous mundus inversus, eliciting tears of joy from "a boy who has been queer all his hour and it's suddenly made all right by a general upheaval of justice." Perpetuating the humiliation of silenced "natures," Eliot's deletions obscure Nightwood's political objective correlative - the carnivalesque crowning of inversion.

Prefiguring the deletion of MacClusky's crowning, Eliot commits an editorial Freudian slip by omitting a reference to the power of silence itself in the novel: "She was the personification of powerful and willful silence!" (Ms., 133). In this passage recounting a conversation between Felix and Matthew, Robin's silence is portrayed as a deliberate and strenuous deviation from the patriarchal script she is asked to perform by her husband, which she and Matthew defy throughout the novel. ${ }^{21}$ One key paragraph in this chapter of the published version of the novel - "Where the Tree Falls" - is actually rendered unintelligible by the editorial deletions surrounding MacClusky's crowning. In this same conversation, the Baron Felix Volkbein explains his misguided assumption that Robin had reciprocated his desire to marry: "'I took it,' the Baron interjected, 'for acquiescence, thus making my great mistake' " (113). The reader of the edited version of Nightwood cannot decipher what "it" means: namely, silence itself. The political implications of the assumption that silence and acquiescence are synonymous lie at the heart of Felix's marriage in particular and the Holocaust in general. This misguided assumption leads Felix into a marriage that places him "in the dark for the rest of my life" and leaves non-Aryans in the darkness of ovens and imposed silence.

Having contrasted the mundus of the Volkbeins with the inversus of Marie, Ludwig, and the culminating carnivalesque crownings of MacClusky and O'Connor, the stage is set in chapter 2 for the entrance of Nightwood's most heroic invert, Robin Vote. Far from acquiescent, Robin's "powerful and willful silence" constitutes an aggressive "gesture histrionic" against the euphemistic "hygiene" of "good women" and "good housewives," no less than the "silencing cover" of fascism itself:

On a bed, surrounded by a confusion of potted plants, exotic palms and cut flowers, faintly over-sung by the notes of unseen birds, which seemed to have been forgotten - left without the usual silencing cover, which, like cloaks on funeral urns, are cast over their cages at night by good housewives - half flung off the support of the cushions from which, in a moment of 
threatened consciousness she had turned her head, lay the young woman, heavy and dishevelled. (34)

These same "good housewives" - angels of the hearth and self-appointed censors of the Night - prove responsible for the internalized oppression that drives Ludwig to suicide in the deleted passages at the beginning of "La Somnambule." But Robin's dishevelled rebellion against these domestic guardians successfully advances the process of carnivalesque redemption inaugurated by Matthew and MacClusky. Representing a composite pre-Oedipal, archetypal collective unconscious free from the threat of fascistic cultural consciousness, ${ }^{22}$ Robin is transgressive even in sleep. A "born somnambule, who lives in two worlds" (35), Robin has "half flung off" the funereal cloaks of culture and will ultimately use the natural world as an escape route from essentialist Aryan cages.

Just as "Rabelais' basic goal was to destroy the official picture of events" (439), so the "chiefest danger" in Nightwood is the stasis of "a 'picture' forever arranged" (37). Flying in the face of these static mundus "pictures" is Robin Vote, "a woman who is beast turning human." As such, Robin epitomizes the redemptive potential of mundus inversus inversion: "She was always holding God's bag of tricks upside down" (113). Mobilized by the double vision of Bakhtin's two worlds, Robin as the personification of mundus inversus unites the "converging halves of a broken fate" (38), repairing the "severed halves" of cusps ${ }^{23}$ ranging from day/night, human/beast, history/legend, culture/nature, male/female, conscious/unconscious, crowning/humiliation, and upper and lower bodily strata. Where inversion is based on arrested development, tragic stasis, and incompletion, the mundus inversus world of Nightwood emanates from pre-Oedipal androgynous unities and the mobility that facilitates comic weddings of cusps. Consistently eliding the second halves of these cusps, Eliot's editorial deletions sever the "converging halves of a broken fate," thus obscuring the redemptive function of anomaly in culture.

According to the theory of anomaly espoused by Hélène Cixous and Catherine Clément, alienated groups reflect one another, constituting their own symbolic structure that implicitly challenges cultural authority and can, if mobilized, even disrupt it. ${ }^{24}$ Reflecting this paradigm in the context of the impending Holocaust, Jane Marcus contends that Eliot's editorial conservatism extends beyond the realm of sexuality, including "editorial cuts of passages that seem overtly homosexual or questionably anti-Semitic" (229), categories of "the other" that are complementary in terms of what Cixous and Clement call the "cultural function of the anomaly" (7). In Nightwood, the interconnected symbolic statures of the novel's outlaw protagonists are underscored in key deleted passages, including O'Connor's description of himself as "one who, in common parlance is called a 'faggot,' a 'fairy,' a 'queen' " (Ms., 88). Eliot's handwritten marginal note on the original manuscript reads, "Might better be out?", a rhetorical question met with Barnes's silence if not acquiescence. Within 
this deleted manuscript quotation, the progression is upward from the common faggot to the mock royalty of the fairy queen. This mobility ${ }^{25}$ is, by definition, antihierarchic insofar as it undermines the static structures of privilege itself, thus defying Aryan ethics that threaten the protagonists of the Night.

Until the last chapter of the novel, Dr. Matthew-Mighty-grain-of-saltDante-O'Connor acts as the voice of this mundus inversus mobility, transforming humiliation into carnivalesque crowning. Like Rabelais' Friar John, Matthew "is a connoisseur of 'all that concerns the breviary' " of the Night: "This means that he can reinterpret any sacred text in the sense of eating, drinking, and eroticism, and transpose it from the Lenten to the carnival 'obscene' level" (Bakhtin, 86). In so doing, Matthew travesties Nazi mundus, effecting a "reversal of the hierarchic levels" (81). ${ }^{26}$ This role was even more pronounced before Eliot's editorial deletions which, above all, seem premeditated to reduce Matthew's role as prophet of the Night, making the final chapter particularly difficult to interpret. The brevity of this chapter is the direct result of the absence of Matthew's shamanistic editorializing. But having been versed in the mundus inversus Gospel according to Matthew throughout the foregoing seven chapters, the reader of the complete manuscript can interpret the novel's concluding bestial parable as the apotheosis of carnivalesque crowning. According to the logic of inversion, Robin's ultimate regression is a redemptive (d)evolution, the completion of her progressive personification of Nightwood's unadulterated collective unconscious.

Even in the published novel, Matthew prophesies Robin's final mundus inversus ritual on several occasions. As a prelude to the final chapter, Matthew's anecdote about Golden Gate Park ducks provides a bestial emblem of the extent to which hygienic acculturation has threatened Robin's nature during the course of the novel:

"Well, then, that's why you are where you are now, right down in the mud without a feather to fly with, like the ducks in Golden Gate park - the largest park in captivity - everybody with their damnable kindness having fed them all the year round to their ruin because when it comes time for their going south they are all a bitter consternation, being too fat and heavy to rise off the water, and, my God, how they flop and struggle all over the park in autumn, crying and tearing their hair out because their nature is weighted down with bread and their migration stopped by crumbs." (160-61)

The setting of Robin's first appearance in the novel - "a jungle trapped in a drawing room" (35) - directly corresponds to "the largest park in captivity." In their attempt to domesticate Robin "by taking [her] in at night like a bird-coop" (164), her lovers have hobbled her nature with the weight of misguided culture, effectively crippling her metamorphic cusp 
mobility in the same way that the ducks' "natures" are perverted and "their migration stopped by crumbs." The real question at the center of the final chapter, "The Possessed," is whether Robin has become too "weighted down" or "fat and heavy" to successfully regress back into the natural "formless sea" of the androgynous and bestial unconscious unsullied by Aryan cultural paradigms.

Evidence of the grave threat of cultural obesity abounds in the beginning of the final chapter, exemplifying the encroachment of the drawing room in the jungle: "it was as if the motive power which had directed Robin's life, her day as well as her night, had been crippled" (167). Robin is domesticated to the extent that she actually temporarily takes on characteristics of the angel of the hearth that were, in the original description of her cusp mobility, juxtaposed as opposites to her "forgotten" nature:

Moving like a housewife come to set straight disorder in an unknown house, she came forward with a lighted taper, and setting it up, she turned, drawing on her thick white gloves, and with her slow headlong step, left the church. (167)

In the initial description of Robin's "awakening" in "La Somnambule," these "good housewives" threaten her nature with "the usual silencing cover, which, like cloaks on funeral urns, are cast over their cages at night" (34). As savior of the Night, with or without Matthew's prophetic chorus, Robin must transform the censorious silence of these "good housewives" into an eloquent resurrection or rebirth into the unconscious, beginning with the exorcism of the "white gloves" of domesticity that can turn, in a moment of "threatened consciousness," into fatal captivity.

Nora Flood, the first lover who tries to tame Robin, is portrayed as the "good housewives' " double; she is 'a 'good woman,' and so a bitch on a high plane, the only one able to kill yourself and Robin! Robin was outside the 'human' type - a wild thing caught in a woman's skin, monstrously alone, monstrously vain" (146). This domesticating abuse of Robin's redemptive monstrosity is duplicated by her second homosexual lover, Jenny Petherbridge, in the final chapter. When Robin begins stalking wild animals, honoring "engagements [which] were with something unseen" (recalling the "unseen birds" of her original portrayal in "La Somnambule"), a hysterical Jenny accuses Robin of "sensuous communion with unclean spirits" (168). These accusations threaten to befoul Robin's preliminary communion with the natural world, her ceremonial cleansing in advance of her ultimate escape from cultural fascism through regression into bisexuality, bestiality, and other primitive syzygy of the collective unconscious. Jenny even tampers with the more traditional rituals of Robin's votive ceremonies:

A moment later Jenny, who had followed her, looking about to be sure that she was unobserved, darted up to the sconce, 
snatched the candle from its spike, blew it out, re-lit it and set it back. (167)

This sacrilege seems gratuitous, even from a character as debased as Jenny, unless she anticipates the wildly transgressive nature of Robin's final ritual. Accentuating the doubling of Jenny and Nora as "good housewives" (mundus), Robin flees Jenny to perform her countercultural ritual in a "decaying chapel" in "Nora's part of the country" (168).

Ascending to the "top of the hill," a site befitting a latter-day savior, Robin's final reunion with her mundus inversus $\mathrm{dog} / \mathrm{God}^{27}$ constitutes a redemptive (d)evolution through the wedding of gender and species cusps. Approximating the movements of an animal, Robin "circled closer and closer" through the woods to the chapel where "the silence that she had caused by her coming was broken again by insect and bird flowing back over her intrusion, which was forgotten in her fixed stillness, obliterating her as a drop of water is made anonymous by the pond into which it has fallen" (168). Eschewing culture, Robin is absorbed into nature and the anonymity of the collective unconscious, symbolized here by the pond. In this mundus inversus ritual, the "drop" of water is an ascension rather than a "fall." Similarly, since Nightwood portrays a fortunate fall into a prehistorical prelapsarian world before the rise of fascism, the fact that "the night was well advanced" (169) suggests that Robin is in a particularly "well advanced" state of mundus inversus grace.

But in Matthew's absence, there is no Gospel to translate this bizarre scene into a redemptive ritual. Even though she performs her bestial ceremony "[o]n a contrived altar, before a Madonna, [where] two candles were burning" (169), the ritualistic dimensions of the scene eluded T. S. Eliot. In response to his inability to decipher the significance of the candles, Barnes lamented in the margins of the manuscript: "Sample of T.S.E.'s 'lack of imagination' (as he said)" (Ms., 215). Only a carnivalesque imagination reflecting Bakhtin's "two world condition" can recognize the candles as the ritualistic accoutrements of Robin's ultimate achievement of "the converging halves of a broken fate" in Nightwood's final chapter. ${ }^{28}$

Though Nora "accuse[s] Robin of 'sensuous communion with unclean spirits," " her point of view is tainted by her desire to tame Robin, submitting her to the domestication of "good housewives." Too often read as Robin's ultimate degradation, her final act is actually a miracle of redemptive regression, the final wedding of beast and human in a ritualistic dance:

Sliding down she went; down, her hair swinging, her arms held out, and the dog stood there, rearing back, his forelegs slanting ... whining and waiting. And down she went, until her head swung against his; on all fours now, dragging her knees. (169) 
After an entire novel in which mundus inversus values transform "down" into "up" ("May you be damned upward!"), Robin's descent to the floor has salutary connotations; in parallel fashion, the dog is "rearing back" on two legs, metamorphosing toward human stature even as Robin regresses away from it so that they meet halfway. In addition, the description of Robin "on all fours now" has divine connotations, referring back to Matthew's earlier encoded prognostication of Robin's final transcendence: "I'm an angel on all fours, with a child's feet behind me, seeking my people that have never been made, going down face foremost, drinking the waters of the night" (95). Finally "taken by something not yet in history ... some foray in the blood that had no known setting" (44), Robin escapes the "jungle trapped in a drawing room" that threatens her nature. Her escape, a paradigm of inversion, is emblematic - a symbolic ritual liberation of the anomalous protagonists of Nightwood.

In his most lengthy disquisition on the Night's inverted natures, who have "committed the unpardonable error of not being able to exist," Matthew prophesies the exact means whereby Robin will achieve her transmigratory metamorphosis:

"Or walks the floor, holding her hands; or lies upon the floor, face down, with that terrible longing of the body that would, in misery, be flat with the floor; so that no stain of her could ache upon the wood, or snatched back to nothing without aim going backward through the target, taking with her the spot where she made one - " (95)

This paradigm of redemptive regression foreshadows the diction and imagery describing her last rites in the novel:

... until she gave up, lying out, her hands beside her, her face turned and weeping; and the dog too gave up then, and lay down, his eyes bloodshot, his head flat along her knees. (170)

Facing each other flat upon the wood of the floor, "that terrible longing" drives both human and beast to "ache upon the wood" in a final broken gesture of surrender. According to the prophecy above, this gesture, though broken in medias res, represents the ultimate healing of the wounds inflicted by an amputating culture, the wedding of the "converging halves of a broken fate." "[D] ashing his rump now this side, now that, of the wall" separating beasts and humans, the dog, a mundus inversus God, rejoins his "angel on all fours." Weeping with joy at this wedding of cusps, "crying in shorter and shorter spaces" that had heretofore "thrust them apart," they retrace the trajectory of history like an arrow "backward through the target, taking with [them] the spot where she made one." The "lost innocence" of a prelapsarian, pre-Oedipal, pre-Nazi paradise is regained. 
By the time this final chapter is enacted without the Doctor's carnivalesque commentary, the reader should be well versed enough in the Gospel according to Matthew to recognize the equation of "barbarity" and "beauty" previously illustrated on the tattooed dos of Nikka, "the nigger who used to fight the bear in the Cirque de Paris. There he was, crouching all over the arena without a stitch on, except an ill-concealed loin-cloth all abulge as if with a deep-sea catch, tattooed from head to heel with all the ameublement of depravity!" (16). In Nightwood's final chapter, this depravity descends to unprecedented heights. Yet the difficulty of appreciating its barbaric beauty is greatly exacerbated by Eliot's tampering with the thematic integrity of the novel's depiction of culture's war on nature. Despite Eliot's initial editorial advice that Barnes completely delete the final chapter, ${ }^{29}$ what happens between Robin and the dog constitutes an ascension to mundus inversus beauty rather than a duplication of Guido's "bowing down" to fascist barbarity in the first chapter of the novel. But the censorial responses of Nora as witness and Eliot as editor suggest that they still see barbarity rather than beauty. Blind to the ideal realm of Nightwood, the nightmare of Daymetal fascism persists, foreshadowing the imminence of the Holocaust despite the apocalyptic vision of inversion in Nightwood.

Nightwood regresses all the way back to the dawn of history itself when, as Cixous and Clement point out in The Newly Born Woman, the invention of the dichotomous foundation of Western philosophy and culture spawned the kind of hierarchic, exclusionary ethical structures that breed fascism in Barnes's cautionary tale..$^{30}$ Turning this structure on its head through the valorization of inversion, and even destroying it altogether by espousing mobility in the form of androgyny rather than static, exclusionary gender polarities, a more profound commentary on the historical trajectory that culminated in fascism is hard to imagine. The irony is that this wildly transgressive text was canonized by $\mathrm{T}$. S. Eliot, so that "[s]trangely canonized and unread, it [Nightwood] cannot function as a critique of fascism" (Marcus, 222). Restoring the passages deleted by Eliot, especially those that demonstrate the liberation of carnivalesque crownings, will help to usher Nightwood out of its canonical closet.

\section{WORKS CITED}

Altman, Meryl. "A Book of Repulsive Jews? Rereading Nightwood." Review of Contemporary Fiction 13 (Fall 1993): 160-71.

- . "The Antiphon: 'No Audience at All'?" Silence and Power: A Reevaluation of Djuna Barnes. Ed. Mary Lynn Broe. Carbondale: Southern Illinois University Press, 1991: 271-84.

Bakhtin, Mikhail. Rabelais and His World. Trans. Helene Iswolsky. Bloomington: Indiana University Press, 1984.

Barnes, Djuna. The Antiphon: A Play. New York: Farrar, Straus and Cudahy, 1958. 
. "James Joyce." Interviews. Ed. Alyce Barry. Washington, D.C.: Sun and Moon, 1985: 288-96.

—. Ladies Almanack. 1928. Elmwood Park, Ill.: Dalkey Archive, 1992.

. Nightwood. Manuscript. Barnes Collection. McKeldin Library, University of Maryland, College Park.

- Nightwood. 1936. Edited and with an Introduction by T. S. Eliot. New York: New Directions, 1961.

Benstock, Shari. Women of the Left Bank: Paris, 1900-1940. Austin: University of Texas Press, 1986.

Broe, Mary Lynn. Introduction. Silence and Power: A Reevaluation of Djuna Barnes. Ed. Mary Lynn Broe. Carbondale: Southern Illinois University Press, 1991: 3-23.

Carpenter, Edward. The Intermediate Sex: A Study of Some Transitional Types of Men and Women. London: Swan Sonnenschein, 1908.

Cixous, Hélène, and Catherine Clément. The Newly Born Woman. Trans. Betsy Wing. Minneapolis: University of Minnesota Press, 1986.

Curry, Lynda. "'Tom, Take Mercy': Djuna Barnes' Drafts of The Antiphon." Silence and Power: A Reevaluation of Djuna Barnes. Ed. Mary Lynn Broe. Carbondale: Southern Illinois University Press, 1991: 286-98.

Eliot, T. S. Collected Poems 1909-1935. New York: Harcourt, Brace, 1936.

Introduction. Nightwood. By Djuna Barnes. New York: New Directions, 1961.

- Editorial and marginal notes. Nightwood manuscript. Barnes Collection. McKeldin Library, University of Maryland, College Park.

- Selected letters to Djuna Barnes. Barnes Collection. McKeldin Library, University of Maryland, College Park.

Ellis, Havelock. The Psychology of Sex: A Manual for Students. 1933; rept. New York: Emerson, 1972.

Faderman, Lillian. Surpassing the Love of Men: Romantic Friendship and Love Between Women from the Renaissance to the Present. New York: Morrow, 1981.

Field, Andrew. Djuna: The Life and Times of Djuna Barnes. New York: G. P. Putnam's Sons, 1983.

Flanner, Janet (Genêt). Paris Was Yesterday, 1925-1939. Ed. Irving Drutman. New York: Viking, 1972.

Freud, Sigmund. "Female Sexuality." Freud on Women: A Reader. Ed. Elisabeth Young-Bruehl. New York: W. W. Norton, 1990: 321-41.

- "Femininity." Freud on Women: A Reader. Ed. Elisabeth Young-Bruehl. New York: W. W. Norton, 1990: 342-62.

Gerstenberger, Donna. "Modern (Post) Modern: Djuna Barnes among the Others." Review of Contemporary Fiction 13 (Fall 1993): 33-41.

Gilbert, Sandra M., and Susan Gubar. Sexchanges. Vol. 2: No Man's Land: The Place of the Woman Writer in the Twentieth Century. New Haven: Yale University Press, 1989.

Hall, Radclyffe. The Well of Loneliness. New York: Blue Ribbon, 1928.

Joyce, James. Ulysses. 1922; rept. New York: Random House, 1961.

Jung, C. G. "The Psychological Aspects of the Kore." The Archetypes of the Collective Unconscious. Vol. 9, No. 1. Collected Works. Trans. R. F. C. Hull. New York: Pantheon, 1959: 151-81.

Kaivola, Karen. 'The beast turning human': Constructions of the 'Primitive' in Nightwood." Review of Contemporary Fiction 13 (Fall 1993): 172-86.

Kannenstine, Louis F., and Allan Smith. The Art of Djuna Barnes: Duality and Damnation. New York: New York University Press, 1977.

Kent, Kathryn R. “ 'Lullaby for a Lady's Lady': Lesbian Identity in Ladies Alma. nack." Review of Contemporary Fiction 13 (Fall 1993): 89-96. 
Lacan, Jacques. Ecrits: A Selection. Trans. Alan Sheridan. New York: W. W. Norton, 1977.

The Four Fundamental Concepts of Psycho-analysis. Trans. Alan Sheridan. 1973; rept. New York: Norton, 1981.

Lévi-Strauss, Claude. Introduction to the Work of Marcel Mauss. Trans. Felicity Baker. 1950; rept. London: Routledge and Kegan Paul, 1987.

Marcus, Jane. "Laughing at Leviticus: Nightwood as Woman's Circus Epic." Silence and Power: A Reevaluation of Djuna Barnes. Ed. Mary Lynn Broe. Carbondale: Southern Illinois University Press, 1991: 221-50.

McCullough, Frances. "Reminiscences." Silence and Power: A Reevaluation of Djuna Barnes. Ed. Mary Lynn Broe. Carbondale: Southern Illinois University Press, 1991: 365-68.

McIntosh, Christopher. The Swan King: Ludwig II of Bavaria. London: Allen Lane, 1982.

Michel, Frann. "I just loved Thelma': Djuna Barnes and the Construction of Bisexuality." Review of Contemporary Fiction 13 (Fall 1993): 53-61.

Muir, Willa. Belonging: A Memoir. London: Hogarth, 1968.

O'Neal, Hank. "Reminiscences." Silence and Power: A Reevaluation of Djuna Barnes. Ed. Mary Lynn Broe. Carbondale: Southern Illinois University Press, 1991: 348-61.

Plumb, Cheryl. "Revising Nightwood: 'a kind of glee of despair.' " Review of Contemporary Fiction 13 (Fall 1993): 149-59.

Proust, Marcel. Sodome et Gomorrhe. 1921; rept. Paris: Gallimard, 1954.

Sartre, Jean-Paul. The Family Idiot: Gustave Flaubert, 1821-1857. Trans. Carol Cosman. Chicago: University of Chicago Press, 1981-93.

Smith-Rosenberg, Carroll. "The New Woman as Androgyne: Social Disorder and Gender Crisis, 1870-1936." Disorderly Conduct: Visions of Gender in Victorian America. New York: Oxford University Press, 1985: 245-96.

Stein, Gertrude. Everybody's Autobiography. 1937; rept. London: Virago, 1985.

- The Making of Americans. 1925; rept. New York: Harcourt, Brace and World, 1962.

Stevenson, Sheryl. "Writing the Grotesque Body: Djuna Barnes' Carnival Parody." Silence and Power: A Reevaluation of Djuna Barnes. Ed. Mary Lynn Broe. Carbondale: Southern Illinois University Press, 1991: 81-91.

Watson, C. L. "Mr. Eliot Presents Miss Barnes." Brooklyn Daily Eagle, March 7, 1937: 16C.

Woolf, Virginia. A Room of One's Own. 1929; rept. New York: Harcourt, Brace, Jovanovich, 1957.

—. Three Guineas. 1938; rept. New York: Harcourt, Brace, Jovanovich, 1966.

\section{NOTES}

1. Where the criterion of genocide was Aryan racial "cleansing," what might be called gendercide motivated the annihilation of those who thwarted the myth of gender and heterosexual "purity."

2. In his letter dated August 12, 1936, Eliot justifies his deletion of key passages in the Doctor's mundus inversus discourse: “Not that the Doctor's conversation flags at all, but simply because I think that too much of it distorts the shape of the book. There is a good deal of the book besides the Doctor, and we don't want him to steal everything. I hope that you will be satisfied when you see the proof, which should be ready in a few weeks. I don't think that I have taken any unfair advantage of the liberty which you have allowed" (Barnes Collection). The "good 
deal of the book besides the Doctor" is a reference especially to the relationship between Nora and Robin.

Cheryl Plumb's "Revising Nightwood" provides invaluable information about both Emily Coleman and T. S. Eliot's editorial input during the decade-long composition of the manuscript.

3. This excerpt from the letter to Peter Hoare dated January 18, 1965, is quoted by Mary Lynn Broe in Silence and Power (299). A similar anecdote is provided in Willa Muir's memoir Belonging (1968), in which she describes Barnes and Eliot at a performance of Molière's Misanthrope in Cambridge, Massachusetts: "Djuna Barnes, who had known Eliot since he was a very young man in Paris, was treating him with easy, affectionate camaraderie and he was responding with an equally easy gaiety that I had never seen in him before. As I put it to myself: Tom Eliot is much more human here than in England. He was less deliberate, less cautious, smiling more easily, spontaneous in repartee, enjoying the teasing he was getting from Djuna" (294). Although Barnes did "humanize" Eliot by penetrating through his "cautious" propriety, her demeanor of "rakish adventure" could not completely soften his "English drilling" (295), especially in print.

4. Unwittingly duplicating Eliot's propriety, biographer Andrew Field misquotes this quip as "He [Eliot] kept his Auden in the Church" (Djuna, 235). Though less intelligible, this version clearly has the "virtue" of being less sacrilegious to Eliot as the high priest of Modernism.

5. Eliot's Introduction was also harshly criticized in the United States, where the novel fared much less famously. In addition, Barnes points out that Eliot did not write an introduction to the first edition, and shrouds this fact in an implicitly negative mystery (O'Neal, 354).

6. Apparently there was a parallel demise in their mutual esteem. Although Eliot prided himself that the publication of Nightwood was the "primary achievement of his career at Faber" (Field, 18), he published The Antiphon out of duty and friendship, despite his colleagues Edwin Muir and Dag Hammarskjold's enthusiastic support of the play's genius (21).

7. See especially Freud's "Female Sexuality" and "Femininity" and Lacan's Ecrits and The Four Fundamental Concepts of Psycho-analysis.

8. Virginia Woolf insists in Three Guineas that so-called feminists "were fighting the tyranny of the patriarchal state as you are fighting the tyranny of the Fascist state" (102). In A Room of One's Own, Woolf is especially virulent in her attack on "unmitigated masculinity" when she argues that "one may question the effect of it upon the art of poetry. ... Poetry ought to have a mother as well as a father. The Fascist poem, one may fear, will be a horrid little abortion" (103). Like Barnes, Woolf advocates androgyny as a means of subverting the dangers implicit in gender tyrannies, including fascism.

9. In Sexchanges, Sandra M. Gilbert and Susan Gubar cite Lillian Faderman's Surpassing the Love of Men and Carroll Smith-Rosenberg's "The New Woman as Androgyne" as seminal works questioning the self-proclaimed libertarian views of these sexologists. Like Freud, though their discourse disrupted Victorian repression and moral rigidity, they remained locked in the premise of inversion as liminal and deviant rather than as a central and redemptive.

10. Gilbert and Gubar's Sexchanges provides a concise account of how sexologists, including Ellis, Carpenter, and Krafft-Ebing, were "popularizing a view of sexual deviance" (216) that was translated by Radclyffe Hall into The Well of Loneliness (see especially part 3, "Reinventing Gender"). Barnes eschews this early scientific, prepsychoanalytic model just as she defies Freudian paradigms of the censorship of innate bisexuality in favor of a more Jungian approach to androgyny as an archetype of spiritual transcendence. The most influential sexological works include Edward Carpenter's The Intermediate Sex and Havelock Ellis's The Psychology of Sex. 
11. In " 'I just loved Thelma', Frann Michel analyzes Barnes's approach to contemporary sexologists' representations of inversion as innate or essential, "the precursor to the genetic argument" (560). According to Michel, though Evangeline Musset in Ladies Almanack "approximates the sexological accounts, dominant in the 1920s, of female homosexuality as innate gender inversion," this essentialist representation is defied by the characterization of "Saint Musset's role as evangelist for the sect [who] demonstrates that she can win converts" (56). Therefore, Michel concludes that bisexuality in Barnes's oeuvre can be "understood as one way of acknowledging the complexity of sexuality ... [which] serves as a challenge to essentializing dichotomies" (55). In the same issue of the Review of Contemporary Fiction, Cheryl Plumb explores the antiessentialist characterization of Robin's bisexuality ("Revising Nightwood," 151-52). In addition, Kathryn R. Kent denies Barnes's collaboration with "sexology's stereotypes of lesbian penis envy" by reading Dame Evangeline Musset as "both a figure of Barnes's appropriation of the phallic and a representation of possibilities for the (re)productive power of lesbian desire" whereby Barnes "co-opts the phallus and denaturalizes its relation to actual penises, at the same time separating it from a strictly masculine and heterosexist context" ("Lullaby for a Lady's Lady"). Finally, Meryl Altman provides a particularly compelling critique of the relationship between racial and sexual essentialism in Nightwood: "I am beginning to see that this equation has its roots in an essentialist discourse about race and eugenics whose father is probably Darwin, whose most famous grandson is Hitler, but whose practitioners in between included both the infamous Viennese anti-Semite and misogynist Otto Weininger, the pioneering spokesman of homosexual liberation Magnus Hirshfeld, and such more ambiguous figures as Havelock Ellis and Sigmund Freud" ("Book of Repulsive Jews?" 164). Like Jane Marcus, I assume Barnes's self-conscious manipulation of these stereotypes of inversion and essentialism rather than her blind adoption of homophobia and anti-Semitism.

12. In "Laughing at Leviticus," Jane Marcus reads Nightwood as "a prophecy of the Holocaust, an attack on the doctors and politicians who defined deviance and set up a world view of us and them, the normal and abnormal, in political, racial, and sexual terms" (249). Marcus's essay is the single most impressive and trenchant analysis of Nightwood to date, and my reading of Barnes has been most influenced by this article.

13. Responding to Barnes's methodological connection between Modernism and Medieval carnivalesque grotesque realism, seminal critics, including Sheryl Stevenson and Louis Kannenstine, also explore the ambivalent marriage between the carnivalesque and the canonical in Barnes's oeuvre.

14. See especially "The Psychological Aspects of the Kore," in which Jung explores the ritualistic value of the anima embodied in the Greek cult of Demeter. No such religious expression of what might be called a "two gender condition" persists in modernity.

15. In the context of Mikhail Bakhtin's argument, mundus inversus has been deemed intrinsically conservative because it temporarily travesties rather than permanently subverts official culture: "[t]he king's attributes are turned upside down in the clown; he is king of a world 'turned inside out' " (370). Yet in generic terms, mundus inversus has the potential to transform the static and therefore potentially tragic hierarchic status quo (mundus) into the transgressive mobility of comedy when, as in the case of Nightwood, the comic mode is revolutionary as opposed to conservative. Barnes's Modernist version of mundus inversus is much more radical, dispensing with kings altogether and replacing them with inverts, queens, and androgynes whose kingdom - Nightwood itself-completely subsumes Daymetal culture within the first few pages of the novel.

16. In Sexchanges, Gilbert and Gubar contend that Matthew O'Connor "resembles the witch doctors, shamans, and berdaches of primitive cultures who have 
traditionally used women's garb, women's medicinal crafts, and even selfcastration as a sign of their dedication to female powers" (361). They also acknowledge the spiritual depth of the androgyne in Nightwood, allying "the transsexual with the transcendent" (360).

17. In the mundus inversus kingdom of Nightwood, true nobility is natural in a manner akin to Shakespeare's As You Like It, in which the court is so corrupt that true nobility is only possible in the green world. It is instructive in this context to note that Matthew's comment that "[w]e may all be nature's noblemen" (15) immediately precedes his distinction between official history - "the best the high and mighty can do" - and legend - "the best a poor man may do with his fate." Where "history ... is deflowered," "[l]egend is unexpurgated," at least until Eliot's editorial intervention.

18. See especially Gertrude Stein's The Making of Americans, in which stylistic repetition duplicates characters' undeviating adherence to their "bottom natures."

19. Among Ludwig of Bavaria's heart-wrenching entries describing his "anguish of sexual guilt and repression" (McIntosh, 159), the following from his "Secret Diary" is particularly poignant:

I swear and solemnly vow by the pure and holy sign of the Royal Lilies inside the impassable, invulnerable balustrade enclosing the Royal Bed, during the year just begun as much ever possible bravely to resist every temptation, and never to yield if at all possible either in acts or in words, or even in thoughts." (dated New Years, 1873)

His last entry in the Secret Diary on June 7,1886 is ominous in its finality:

1st June definitely the last full 2 months and 3 weeks
before the 41 st birthday
You remember Sire
Remember
Remember
From henceforth never!
From henceforth never!
From henceforth never!!!
Sworn in the name of the Great King
now invoking the puissant aid of the Redeemer.
Linderhof
(Also from kisses strictly to abstain
I swear it in the name of the King of Kings.)

20. In "Revising Nightwood," Cheryl Plumb contends that MacClusky was "the original name for O'Connor" in early manuscript versions of the novel. By splitting MacClusky off into a separate character, the scope of androgynous mundus inversus and carnivalesque crowning is extended beyond savior and prophet (Robin and Matthew) into the ranks of common foot soldiers acting as foils to Hedvig's Nazi, perverted androgyny.

21. Explicitly addressing the role of Robin's silence in the manuscript, Barnes explained to Emily Coleman: "I do not want to connect her in any way with the present temporal world as we know it, it is why I did not let her say more than two words for herself in the book" (letter dated November 8, 1935; quoted in Plumb, 156). In "Revising Nightwood," Plumb suggests that this silence "encourages readers to see Robin as a timeless being who carries the mythic theme of female ruin of the original 'Run, Girls, Run' " (156). I differ from Plumb's reading of Barnes's intent insofar as I see Robin's silence as her means of transcending rather than 
epitomizing the patriarchal plot of "female ruin." My reading seems more in keeping with Robin's lack of connection with "present temporal" gender restrictions.

22. Karen Kaivola corroborates this reading of Robin as a composite preOedipal, archetypal collective unconscious when she cites "Freud, who charted a 'dark continent' within each individual and whose theories of subjectivity locate within each one of us a conflict between powerful forces figured as primitive and the more tenuous forces of civilization. Personifying the unconscious and the instinctual, Robin seems more primitive than the other central figures" (175). Though I credit Kaivola's approach, I see Nightwood more in Jungian than in Freudian terms.

23. This term, rather than "binary oppositions" or "dualities," reflects Nightwood's transcendence of or transgression against polarities and hierarchy in favor of androgynous continua. Questioning "dual hierarchical oppositions" as the foundation of Western philosophical discourse, Hélène Cixous and Catherine Clément point out the inherent dangers in "the fact that Logocentrism subjects thought all concepts, codes and values - to a binary system, related to 'the' couple, man/ woman" (64). Though Cixous and Clément acknowledge the hermaphrodite's implicit potential to belie this binary fallacy, they regret that traditionally bisexuality or androgyny has been "dominated by masculinity" and "locked up tight between father and son" (55-56). Barnes reintroduces the female principle in the androgynous mythic sequence by characterizing Robin as both mother and immortal androgyne.

24. See especially The Newly Born Woman, in which Cixous and Clément cite comparable arguments about the function of cultural anomaly in Claude LéviStrauss's Introduction to the Work of Marcel Mauss and Jean-Paul Sartre's The Family Idiot (7-8). Similarly, in "A Book of Repulsive Jews?" Meryl Altman analyzes the way in which "the book about Others" conflates its cast of outsiders, especially homosexuals and Jews: "Jewishness seems inextricably wedded to sexual deviance and ambiguity" (164), a Modernist wedding already established by Proust in Sodome et Gomorrhe and by Joyce in Ulysses. In addition, Altman contends that " $(\mathrm{h}]$ omosexuality works as an ethnic or racial sign, much like Jewishness" (164); as a result, "Jewish characters can also function ... as sympathetic outsiders whose linguistic and social positioning ... enables the authors to develop large-scale analogies to other cultural out-groups" (163). In "The "beast turning human,' "Kaivola advances a similar thesis when she argues that "Felix's action functions metaphorically for what is presumed to be true of the other cultural outsiders as well" (174), a point also taken up by Shari Benstock in Women of the Left Bank (174). Clearly, Altman's, Kaivola's, and Benstock's readings of Nightwood exemplify the theories of anomaly and alienation propounded Cixous and Clément.

25. In The Newly Born Woman, Cixous and Clément cite symbolic mobility, especially the "incompatible synthesis" of bisexuality, as a primary force of cultural revolution: "And like all the subgroups that are unsituated in the complex of symbolic systems, women are threatened by the reverse of mobility, by symbolic repressions that are ready to limit the effects of symbolic disorder" (8). It is significant that Robin's mobility or wandering is what most disturbs Nora; as the androgynous somnambule who is mobile even in sleep, Robin Vote is the epitome of "symbolic disorder" in the form of sexual inversion. Consequently, in Nightwood's mundus inversus world, Robin is valorized rather than stigmatized.

26. According to Bakhtin, this "reversal of hierarchic levels" is best exemplified by the carnivalesque crowning of "the jester [who] was proclaimed king ... at many of these feasts kings and queens were elected for a day, as on Epiphany and on St. Valentine's day" (81). The degradations of King Ludwig of Bavaria and Queen Marie Antoinette in Nightwood provide sophisticated Modernist examples of these carnivalesque paradigms. 
27. In Sexchanges, Gilbert and Gubar read Nightwood "as a revisionary response to male modernists like Joyce and Eliot [wherein] Robin Vote can finally be viewed as a kind of sacred Dog, a reversed God (or Goddess) of the third sex" (361-62). They also point out that the novel's final chapter recalls "the perverse 'Doooog' that haunts both Joyce's nighttown and Eliot's waste land" (361).

28. This night blindness to the symbolic significance of the final chapter is shared by Donna Gerstenberger, who is skeptical of the search for meaning in the conclusion of the novel, criticizing the "need to believe that there is an articulable, if unexpected, answer to the riddle of her [Robin's] being, of love, and of possession" (40-41). Gerstenberger finds Eliot's shantih at the conclusion of The Waste Land to be a much more "historically recuperative answer to what has been, after all, a version of the traditional quest" (as if a statement of resolution actually constitutes real resolution). Conversely, I read Eliot's shantih as "the horror" of ultimate irony; in Nightwood, the joy of mundus inversus displaces or reverses Modernist irony.

29. In her account of the compositional and editorial history of the Nightwood manuscript, Cheryl Plumb notes that Eliot's initial response to the book jibed with Emily Coleman's insofar as he counseled the deletion of the final chapter, "The Possessed": "he had read the book as the Doctor's story and suggested 'strongly' the omission of the last chapter, 'which is not only superfluous, but really an anticlimax'" (154). Apropos Barnes's comment in the margins of the final page of the manuscript - "Sample of T.S.E.'s 'lack of imagination' (as he said)" - Barnes was consistently impatient with readers, including her editor, who did not understand the crowning significance of "The Possessed": "I do not go any further than this into the psychology of the 'animal' in Robin because it seems to me that the very act with the dog is pointed enough, and anything more than that would spoil the scene anyway; as for what the end promises (?) let the reader make up his own mind, if he's not an idiot he'll know" (Barnes, quoted in Plumb, 153). The number of readers who infuriated Barnes by assuming that Robin is attempting to copulate with the dog (see O'Neal, 353) suggests that Barnes would have considered her audience full of idiots.

30. In The Newly Born Woman, Cixous and Clément postulate that Western "[t]hought has always worked through oppositions," resulting in "dual, hierarchical oppositions" that in turn promote misogyny because "[0]rganization by hierarchy makes all conceptual organization subject to man" and "male privilege" (6364). One "way out" is the kind of bisexuality Robin Vote exemplifies, "the other bisexuality, the one with which every subject, who is not shut up inside the spurious Phallocentric Performing Theatre, sets up his or her erotic universe" (84-85). In Nightwood, inversion achieves what Cixous and Clement celebrate as the bisexual "nonexclusion of difference or of a sex . . the multiplication of the effects of desire's inscription on every part of the body and the other body" (85). 